\title{
Impact of an Informal Science Program: Middle School Gifted Science Students
}

\author{
Dr. Abha Singh \\ Western Illinois University, Department of Curriculum and Instruction, \\ Macomb, IL USA 61455
}

\section{ABSTRACT}

This research explores an informal science program (ISP) in fulfilling the needs of talented and gifted middle school students. Specifically, it discusses the need of teachers' continued professional development and the unique challenges and opportunities inherent in instructing gifted middle school students. It further focuses on characteristics of successful teaching strategies and methods for identifying and training teachers. The study uses a constructivist framework to examine teaching methods and suggests that constructivism is an appropriate method for instructing gifted middle school students. The research reflects the results of an embedded descriptive multiple case study of six teachers in the informal science program, an initiative to provide middle school students in rural midwestern states with opportunities for accelerated learning in science.

\section{Indexing terms/Keywords}

Constructivism, Informal Science Program, Professional Development, Acceleration.

\section{Academic Discipline And Sub-Disciplines}

Science Education; Gifted Education;Education

\section{SUBJECT CLASSIFICATION}

Education

\section{TYPE (METHOD/APPROACH)}

Quasi-Experimental; Literary Analysis; Survey/Interview; Qualitative

\section{Council for Innovative Research}

Peer Review Research Publishing System

\section{JOurnal: INTERNATIONAL JOURNAL OF RESEARCH IN EDUCATION METHODOLOGY}

Vol 5, No. 2 


\section{INTRODUCTION}

Current research reveals that there are few resources available to talented and high ability elementary learners in science. There are studies that focus on design, development of science curriculum for gifted elementary learners, but very few on the effectiveness of exciting elementary science curriculum for gifted learners (Adams \& Pierce, 2007).

Project 2061's Benchmarks for Science Literacy (American Association for the Advancement of Science, 1993) and the National Science Education Standards (National Research Council, 1996) are the foundation for many school districts, and are used widely for gifted learners in science. However, in 2002, the No Child Left behind Act (NCLB) was signed into law, which modified the definition of gifted and talented students. The "No Child Left Behind" act focuses on developing "proficient" science abilities in all students. The development of the gifted science student's "advanced" talent is not a priority. Therefore, school organizations are not open to change and reform in science education for the gifted learner.

Most educators of the gifted have concerns that experiences of advanced learners are being overlooked in middle schools where advanced learning is deemphasized and where few teachers are trained to understand advanced learners (Ford, 1994; Kerr, 1985). It has also become evident that elementary teachers may tend not to teach science because they lack content knowledge or feel insecure with it as a subject area (Rutherford \& Ahlgren, 1989). Little instructional time in elementary schools has been devoted to science (NAEP, 1999); and where science was taught, basal texts that emphasized reading and canned experiments were preferred and used over active learning (Lockwood, 1992a, 1992b).

If the desire is to improve teaching and focus on student learning, then teachers need help in teaching for understanding (Cohen, McLaughlin, \& Talbert, 1993). In order to do that, we need to emphasize strategies and instructional approaches in the context of content rather than separate from it. Inquiry teaching requires that students combine scientific knowledge with reasoning and critical thinking to develop their understanding of science (NRC, 1996, p. 6). Recent trends focus on teacher professional development; collaborative models like The Gifted Education Center's Dynamic Model for Professional Development and Curriculum Improvement were designed to engage modern teachers in inquiry-based, longitudinal, and critical examinations of their instructional methods. These initiatives extend professional development activities from formal settings (e.g., teacher workshops) into authentic communities of practice (e.g., classrooms).

\section{Problem of Research}

What themes emerge that characterizes the teaching practices of the science teachers (from the Professional Development efforts and observations)? How do the science teachers describe the needs and the experiences provided for the gifted students enrolled?

\section{Research Focus}

Effective teaching is the vision of science education described in the National Science Education Standards. Many of the fastest-growing occupations in the nation require strong math and science skills, and extensive training beyond the high school level. Unfortunately, not enough high school students are receiving the training they need to compete in these subject areas in higher education or career fields.Current research reveals that there are few resources available to talented and high ability elementary learners in science. There are studies that focus on design, development of science curriculum for gifted elementary learners, but very few on the effectiveness of exciting elementary science curriculum for gifted learners (Adams \& Pierce, 2007).

\section{Methodology of Research}

A descriptive embedded multiple case study was designed to document the experiences of six science teachers who participated in the program with regard to their knowledge of science, and constructivism and the teaching methodologies they employed both before the program and afterwards (Merriam,S.B.,1998). The six teachers filled out surveys (see Appendices A, B \& C) before the Extracurricular Science Program and afterwards to determine any changes in their perception as a result of professional development geared toward constructivist learning theories.

\section{General Background of Research}

Historically, tension has existed between gifted education and traditional middle schools, leaving some advocates of each educational practice suspicious of the other, and leaving middle school students who are advanced in one or more dimensions of learning in a sort of educational no-man's land (Tomlinson, C,1992). A major problem in the middle school that affects these gifted adolescents is that middle school educators stress development of school environments in which early adolescents can belong to a nurturing group and can have consistent access to adults who care about their social needs. Sometimes this has the unintended consequence of minimizing the students' intellectual needs (George, P., \& Shewey, K. ,1994).

Most educators of the gifted have concerns that affective experiences of advanced learners, which sometimes lead to situations where the teacher finds it a challenge to keep up with the students' academic needs leads to students being overlooked in middle schools. Advanced learning is then deemphasized, particularly considering that few teachers are trained to understand advanced learners. On the instructional side of science, studies have shown that elementary school teachers may not have been teaching science because they do not feel comfortable enough with the content (Ford, D. ,1994).As a result, little instructional time in elementary schools has been devoted to science (Rutherford, J., and Ahlgren, A. ,1989); and where it was taught, basal texts that emphasized reading and canned experiments have been preferred 
over active learning methodologies (National Assessment of Education Progress, 2000\& Lockwood, A.,1992a \& Lockwood, A., 1992b).

Tobin, K. (1998) claimed that science teachers influence what and how students are taught and thus affect student achievement. Varrella, G.F. (1997) studied the relationships between individual teachers' beliefs and their teaching practices and found that beliefs could be changed if teachers were given the opportunity to learn and become successful with different teaching styles. If the teacher's desire was to improve teaching and focus on student learning, then teachers need help learning to teach with the goal of attaining a student's understanding of the material. In order to accomplish understanding, teachers need to emphasize strategies and instructional approaches within the context of content rather than separate from it (Cohen, D., McLaughlin, M., \& Talbert, J. 1993).

\section{Sample of Research}

The teachers in the ISP were chosen by the school district based on various factors, including possessing a teaching license for middle school; and endorsements and certification at the secondary level in biological science, chemistry, physics, general science, earth science, physical science and/or mathematics. Attendance at professional development every summer at the Gifted Education Center was also a requirement for the teachers participating in the ISP.

Other factors that contribute to teacher selection were enthusiasm, expertise in middle school education, a willingness to learn and collaborate with others, unique teaching methods, and perhaps most importantly, creativity in teaching aboveaverage middle school science and math students.

The teachers selected for the ISP have many responsibilities that require vigorous practice. The instructors begin their leadership "practice" by participating in mandatory professional development during the summer. Once the teacher has successfully completed this requirement he or she is provided with the curriculum units for the middle school semester and is then assisted with resources and mentoring by experts in the fields from the University.

The teacher helps identify students from their schools by nominating children for talent discovery. They must also familiarize themselves with equipment and technology recommended for inclusion in the Mitchell Curriculum. During this intensive work period, teachers are collaborating with other ISP teachers from other participating school districts while also partnering with coordinators of the program. The teachers learn to work directly with the district ISP coordinator; who is assigned to communicate with families, school administration, and the Gifted Education Center during the school year.

The teachers complete their summer project with an evaluation of the procedures set by school districts and the Gifted Education Center in order to help improve the program for the following summer. Last, the teachers provide feedback to the coordinator, school district, and the Gifted Education Center about progress in their own Excellence classes.

Professional development of science and math teachers is a major component of the Excellence Program. The model used by the Excellence professional development was created by the Gifted Education Center in 1980 and is called the Dynamic Model of Professional Development.

The principal investigator of this project had a single focus: to completely, and as thoroughly as possible, probe the learning by teachers of a professional development program for the teachers who participated in teaching this extracurricular, informal, and nontraditional classroom experience for middle school students identified as having extraordinary - above grade level - abilities in math and/or science. The six teachers who participated in this research project did so willingly and enthusiastically.

As skilled math and science middle school instructors, they were not only avid supporters of the ISP; they also felt compelled to do something on behalf of gifted youngsters everywhere. The participating population consisted of the above-mentioned six science teachers from four rural junior high schools in the Midwest. All six instructors were certified science teachers, with expertise in biology, chemistry, physics, or general science for elementary or secondary areas. The ISP is currently active in five rural school districts in the Midwest.

Table 1 shows information about the six teacher's education, experience, grades they teach and their license to teach at the time of the study. All the science instructors have two or more years of experience teaching science to middle school students 
Table 1. Experience and Teaching License of the Science Teachers

Names Education Experience Grades Taught Licensed to teach

Teacher A $\quad$ BA: Sc Ed years $\quad 7-12 \quad 7-12$ All Sciences

\begin{tabular}{|c|c|c|c|c|}
\hline Teacher B & $\begin{array}{l}\text { BA: Elem } \\
\text { Education }\end{array}$ & 5 years & $\begin{array}{l}\text { Middle \& High } \\
\text { School }\end{array}$ & $\begin{array}{l}\text { 5-12 Gen Science, K-12 } \\
\text { Math, K-8 Basic Sci }\end{array}$ \\
\hline Teacher C & $\begin{array}{l}\text { BS: Science } \\
\text { Education }\end{array}$ & 4.5 years & $\begin{array}{l}\text { Grade 10-12, } 9 \\
\text { science, }\end{array}$ & $\begin{array}{l}\text { 5-12 Chemistry, Physics } \\
\text { and General Science }\end{array}$ \\
\hline Teacher D & $\begin{array}{l}\text { BS: Elementary } \\
\text { Education }\end{array}$ & 35 years & $\mathrm{K}-12$ & $\begin{array}{l}\text { All subjects to K-8 except } \\
\text { Physical Education, Music }\end{array}$ \\
\hline & $\begin{array}{l}\text { MS: Reading and } \\
\text { Testing }\end{array}$ & & & and Art. \\
\hline Teacher E & $\begin{array}{l}\text { BA: Elementary } \\
\text { Education }\end{array}$ & & & K-6 Elementary Education \\
\hline & MA: Public Affairs & & & $\begin{array}{l}\text { Can teach all subjects } \\
\text { excluding art, music, } \\
\text { physical education. }\end{array}$ \\
\hline Teacher F & $\begin{array}{l}\text { BA: Science } \\
\text { Education }\end{array}$ & & & 5-12 Chemictry General \\
\hline
\end{tabular}

\section{Instrument and Procedures}

There are three validated instruments used for this study. The six science teachers prior to professional development answered the instruments and then the same instruments were used after the professional development. The pretest and posttest were used to investigate changes in the science teacher's views regarding constructivist teaching practices, specifically, in regards to the nature of science. The investigator also conducted individual interviews, lasting no more than two hours.

The first instrument is titled "A Scale for Constructivist Teaching Practices" (Enger \& Yager, 2001) Corwin Press.The second instrument involves questions about constructivism (Yager, R. E. 2005). The third research instrument use is titled " The views of Nature of Science Questionnaire - Form C (VNOS - Form C) (Lederman, NG.Abd-ElKhalick,F.,Bell,R.L.,Schwartz,R.S. (2002). Journal of Research in Science Teaching, 39, 6,497-521.

A private, unstructured interview was conducted with each science teacher. As pointed out earlier, these individuals were observed teaching the Excellence middle school extracurricular class on two separate occasions during the academic year. The interviews' objective was to identify the key features of the professional development summer workshops that were actually employed during extracurricular science teaching. A rubric, Expert Science Teaching Educational Evaluation Model (ESTEEM) for a Science Classroom Observation (Barry-Stock, 1995) was used to understand the teachers' methodology. The instrument was able to identify whether the science teacher was an effective "facilitator", were the participating students actively engaged in activities like asking questions, initiating exploration of new material(s) and showing a willingness to collaborate with others in the classroom. The instrument was able to identify whether individual 
teachers were engaged in listening to students' points of view, whether they offered appropriate and informal mentoring and/or whether they encouraged the extracurricular students to apply newly gained knowledge to further their own exploration(s).

Data for this study was collected in three ways during the 2006-2007 academic year: pre- and post-study tests were given to each of the participating teachers, semi-structured interviews were conducted with each teacher regarding his or her experiences, and teachers were observed in the classroom once early in the study and again after three months.

\section{Pre-tests and Post-tests}

The pre- and post-tests were designed to elicit information on three main dimensions of the teachers' thought. First, a "Scale of Constructivist Teaching Practices" was administered to determine the degree to which the teachers were already using and/or invested in constructivist methods. Second, a series of questions about constructivism itself was administered to determine the teachers' understanding of constructivism itself. Finally, a series of questions regarding beliefs about the nature of science was administered to determine the teachers' preconceptions about their subject, in order to contrast those with the results of the post-test.

\section{Interviews}

Interviews with the science teachers were conducted during the summer training sessions, and additional interviews took place during the 2006/2007 academic year. Interviews, which were conducted in person, were audio taped and later transcribed. The content of these questions was designed to elicit the reasons teachers were interested in gifted middle school students, their observations about a need for additional instructional opportunities, and whether they had ever pursued any professional development specifically targeted towards instructing gifted students. A number of related topics were also discussed, including what additions are necessary to existing science teacher training programs, what resources are available for teachers seeking to accommodate gifted students, and whether the teachers noticed changes in their own teaching styles as a result of the ESP professional development program.

Open-ended questions allowed the teachers to reflect on what they knew about science content, the nature of science, constructivism, gifted students and professional development. Opportunities were provided for the instructors to expand on their explanations using personal and professional experiences.

\section{Teaching Observation}

All the science teachers were observed twice in the school year while they were teaching the extracurricular science classes. Audiotapes were made of the classes so they could be analyzed later using a rubric. The first teaching observation was conducted at the beginning of the excellence program, while the second observation was conducted three months later.

\section{Data Analysis}

The data analysis drawn are significant regarding both the research questions posed in this study. In terms of the characteristics of the teachers' methods, it's clear that even when they were unfamiliar with the terminology of constructivism, their teaching styles often broadly (though not exclusively) followed constructivist tenets. This result both reflects and shapes the answer to the second question about the perceived needs of gifted students in science education. Amy summed up these needs, saying, "They simply want and need to learn at their level and need hands on and relevant experiences with science."

The comments from the participants reveal that these individuals felt that the professional development opportunity of this program was productive. This result reinforces The National Research Council's (NRC) support for inquiry as appropriate instruction for gifted science students. Also confirmed were the benefits to both teacher(s) and student(s). NRC published a book, authored by Olson \& Louck-Horsley, (2000) which supports the idea that inquiry instruction for gifted science learner's model current scientific thinking and attitudes.

The teachers' comments reveal their belief that constructivist methodology is a successful tool for teaching gifted science students. Most professionals in the science education field currently consider constructivism to be the most effective way to teach for meaningful understanding (Burry-Stock and Oxford, 1994). This study substantiates what Yager, (1991) and Burry-Stock and Oxford, (1994) concluded; that constructivist teaching methods are most effective in achieving meaningful understanding of science for all students.

When a general science education system is constructed so that flexibility, freedom, and diverse opportunities allow students' potentials to be fully realized, gifted science education is a natural outgrowth. The nurturing, development, and recognition of giftedness within our high schools are derived naturally from a liquid science classroom environment. The invitation must remain open to all students at all times. This study has provided good practical examples of constructivist techniques for gifted students. These improved strategies can be incorporated into the design of future extracurricular programs for not only above-level science learners, but for general middle schools populations as well.

Science education needs to develop programs that honor all learners, including those individuals with unusual strengths in science. An elevation of science giftedness is required in all domains and across cultures to a place of utmost value in our society. Science as an academic pursuit must be free to "bubble up" and move towards a student-oriented and interestbased environment rich with relevant pursuits of knowledge. Young people everywhere deserve a learning environment in which they can transcend our expectations whenever they are ready. 


\section{Results of Research \\ Pre- and Post-Test results}

The pre-and post-tests tended to show that between the beginning and the end of the study there was the greatest change in the teachers' knowledge of constructivism. There was also a significant change in the degree to which their teaching methods followed constructivist ideas, but all six of the teachers were found to have incorporated various constructivist practices into their existing teaching methods, so the move toward constructivism was a shift in degree rather than overarching paradigm. The teachers' views on the nature of science remained largely the same throughout the study. The teachers' views on constructivism go to the heart of the research questions, because they focus on an area where the training the teachers received and their perceptions of student needs intersect. When describing their own training, it became clear that the teachers had experienced constructivist teaching methods when they were students as well as learning about them while training to be teachers.

\section{Emily wrote of a favorite professor,}

In her classes, we had textbooks, but they were used primarily as reading tools and not the primary source of information. She approached the classes as though we were experts on teaching science, which we weren't, but it gave us the chance to think about what we would do as teachers and why. She was also sure to include lots of referenced information so that we could learn from others' ideas.

\section{Sammy noted a similar approach to learning:}

I can read about a subject, try out ideas, and discuss solutions with others. College was probably my best learning situation because the material was sufficiently difficult and I had the opportunity to engage with it as well as discuss it with others and my professor. As a science person, I enjoyed labs because they gave me the opportunity to physically explore concepts discussed in class.

These answers show that some of the teachers had experience with constructivism "from the other side" of the classroom, and that their experiences were generally good. These experiences may have helped shape their own teaching practices and receptivity to constructivist ideas. When it came to their experiences as teachers, they reported beliefs that constructivist teaching methods were beneficial to gifted learners. Sammy said that,

[Constructivism] uses hands-on materials, which plays to some students' strengths. It also recognizes that kids are not "blank slates," that they come to lessons with preconceptions and misconceptions that influence how they will see the lesson content. It plays to the strengths of gifted kids; that is, integration of old and new experiences and abstract thinking.

There were two other key results of the tests. The first was very simple: it turned out that two of the teachers weren't familiar with the concept of constructivism. This was a challenge in the pre-test, as they were unable to answer many of the questions. However, when they learned what constructivism was, they were able to identify both constructivist teaching methods they already employed and ones they were learning about in training.

The second interesting result of the test was the teachers' beliefs about when constructivist teaching methods could appropriately be used. The teachers tended to agree that constructivist methods best met the needs of especially motivated and gifted students, but acknowledged that there were challenges, especially when it came to less-motivated students. Emily wrote:

"It would probably help my performance in a classroom (as a student) because I have the strengths that constructivism leans upon. As a teacher, I think that the high-ability students would respond well to constructivism while lower-ability students would struggle".

She later added,

"I'm still trying to work out how much prior knowledge the students must have for each lab, and how much I can expect them to learn on their own. Teaching in an open-ended format is also challenging because I have to be prepared for a variety of ideas on how to study the same idea, which means I have to know a lot about what l'm teaching and also where to direct students if none of us knows the answer. I've also found this method to be lab-intense, which is good for learning but bad for time management (both in and out of class)".

The difficulties of bringing constructivist teaching methods into the classroom fall into three main categories: the logistical difficulties, which Emily noted in terms of "time management," the legal and curricular requirements regarding what must be taught, and the difficulties of teaching students of varying skill and motivation levels. Nancy mentioned the legal and curricular challenges constructivist methods face:

When you base curriculum on student's prior knowledge/experiences/interests it is difficult to cover the curriculum required. I have certain standards and benchmarks that I must cover. When students take science classes in college they are going to be expected to know some things and some of those things must simply be memorized.

Her concerns touch a very basic part of the pedagogical debate surrounding constructivism-that teachers perceive a conflict between inquiry and interest-driven learning and standardized testing. Three of the science teachers also noted that constructivism assumes students will automatically integrate their hands-on experiences into their view of the world, and that they can think abstractly enough to be able to generalize experiments from a science lab to real-world settings. It presumes that all students learn best by doing things with their hands, which is not necessarily the case. Sammy also 
reiterated "constructivism doesn't take into account standardized testing requirements, curriculum requirements, or instructions from districts that emphasize memorization over understanding."

These observations speak directly to this study's research questions. First, they suggest that training in constructivist methods helps teachers think critically about their teaching styles and the needs of their students. Second, the results point to a need for further research into the perceived conflicts between constructivist teaching styles and the current educational system - specifically, that constructivism is not an appropriate teaching method for all students and that it may be at odds with standardized testing and curriculum requirements.

\section{Results of observations}

The two observations of each teacher provided information in many separate dimensions. On a basic level, it was possible to quantify the number and type of questions each teacher asked, and to make observations about the environments in which they taught. On a more complex level, it was possible to make observations regarding essential features of each teacher's methods, including their techniques for facilitating student inquiry, relating specific evidence to broad concepts, and addressing student misconceptions.

It is important to situate the observations in the context of the research questions because they were focused on student learning, and thus need to be interpreted in dimensions that specifically answer those questions. The results of the observations inform the research questions in two ways: first, they provide insight into the way the teachers' ideas about students' needs translatedinto their actual teaching styles, and second, they provide insight into how the teachers' own training informed their teaching methods.

\section{Questions teachers asked.}

The investigator recorded all the questions the six science teachers asked the students in the ISP classes during both observations. The questions asked were categorized based on Bloom's (1985) Taxonomy. Information based on the two observations indicated an increase in the number of higher order questions during the second observation as compared to the first observation. The first teaching observation was conducted when the Excellence program began, while the second observation was conducted toward the end of the academic year of the ESP. The results regarding the type and number of questions teachers asked are provided in the figure 1 below.

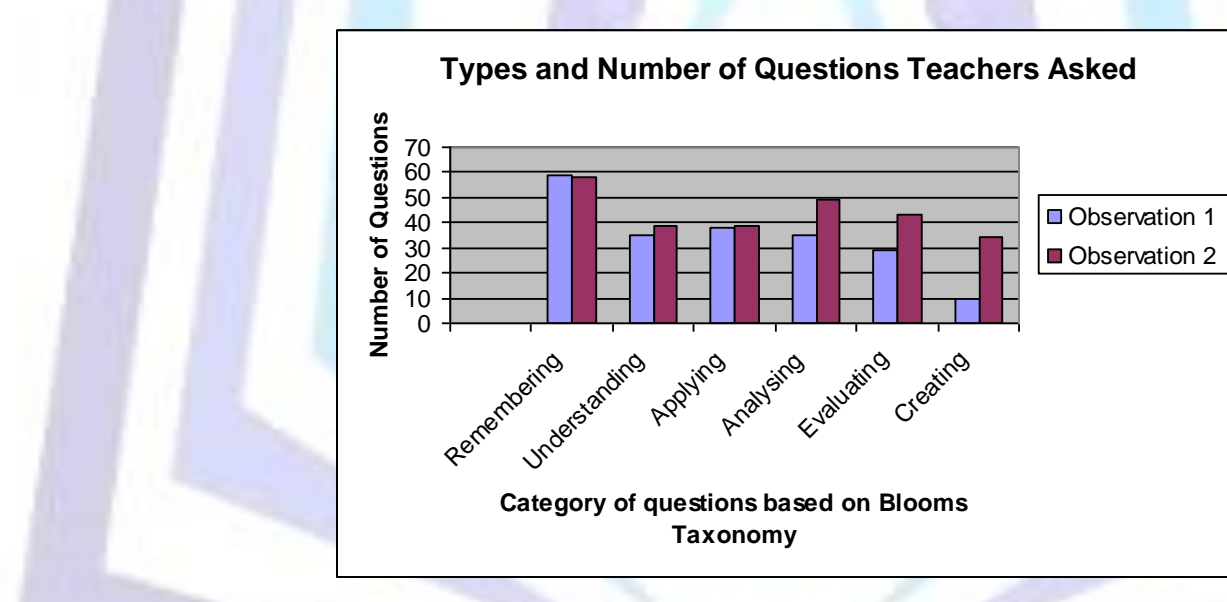

Figure 1. Types and Number of Questions Teachers Asked

Source: Teacher Observations

The chart most importantly shows a $58 \%$ increase in the higher order questions (analyzing, evaluating and creating) during the second observation. It is also important to note that all of Bloom's (1956) categories were represented even in the earlier observations; the teachers were asking higher order questions as a matter of course, though they asked more as the program progressed.

There was also a clear strategy informing the questions the teachers asked. All the teachers began by asking questions to first inquire of prior knowledge about the topic being introduced. They also encouraged the students to hypothesize prior to conducting experiments. The questions promoted higher order thinking, student reflection and exploration of the relationships between the immediate evidence and broader scientific concepts. These techniques were examined during the ESP professional development workshop, as the teachers thought about different ways to approach their curricula. Questions they considered included: "What else can be used instead of this material suggested?" and "How can we get students to think critically?" The answers to these kinds of questions are informed by ideas about what students need, and we can infer from the questions the teachers asked that they felt it was beneficial for the students to explore higher level open-ended questions to gain comprehensive knowledge. 


\section{Learning Environment}

The learning environments themselves revealed various teaching priorities. Two of the science teachers used the classroom and the hallway outside the classroom for an activity exploring rockets. Two teachers took their classes outside in the playground area for a part of the class. Two science rooms' bulletin boards had pictures of noteworthy scientists and their contributions to science. All of the six science teachers displayed student work, as well as current topic related photographs and diagrams. These details can be interpreted as addressing the concern that accelerated learning at the middle school level comes at the cost of social development; the teachers' decisions to display student work along with examples of role models in scientific fields may have helped build a social dimension to accelerated learning by locating students in a community of their peers as well as a larger continuum of scientific thought.

\section{Teachers as Facilitators}

For the most part, all the science teachers took care to ensure that students be responsible for their ownlearning experiences. One teacher encouraged them to pursue their questions after they had written hypotheses. Another asked the students to design and develop their own rockets during the rockets unit, and encouraged the students to consider various priorities, including flight time and height. The students designedand experimented with their rockets, while the teacher asked questions to help them think

through what they were doing.All the teachers were actively engaged in initiating examples, asking questions and suggesting and implementing activities throughout the lesson. In every classroom the teacher connected with each student an individual level. Students' personal investments were apparent in that they came into the class enthusiastically and in most cases stayed for the two hours and did not want to leave right away when the class concluded. This evidence suggests that the constructivist techniques the teachers employed succeeded in motivating the students to take charge of their own learning experiences.

\section{How concepts were related to evidence}

All the science teachers paid careful attention to students' questions in order to help make connections between evidence and scientific concepts. For example, during the unit on rockets the students discovered that wing shape, weight, and speed of launch played a major role when it came to the rocket going higher and faster. They gained an understanding of the concept of flight through practical activities. The teachers checked the students' data and asked questions to encourage them to clarify their findings and translate them into ideas for modifying their rocket design. In most cases the

students knew why they had the data and what they had modified to improve their rockets.

The relationship of concepts to evidence is of special interest given the misgivings the teachers had about whether students are able to make broad inferences from specific data. In this area it's clear that the gifted learners in the ISP program benefitted from the opportunity to draw conclusions, however it's important to remember that there was no control group of students of average talent and motivation against which to compare that information. The teachers' enthusiasm for using constructivist methods to help gifted students learn seems to be justified, but their misgivings about the appropriateness of those methods for the majority of students remain untested.

\section{Teacher efforts to resolve misconceptions.}

All the teachers paid careful attention to clearing student misconceptions as they came along. For example, one student asked the science teacher about how flight occurs; the concern expressed by the student was that the lift occurs because of speed and lightness of the air craft. The student did not understand the concept of air pressure and drag when it came to taking off. The teacher brought in a small fan to show the impact of air on the flight by asking the student to do the activity using wind from the fan. The student was able to uncover the importance of the shape of the aircraft to reduce

drag and provide lift.The overall evidence showed that in all cases the science teachers used probing questions, laboratory resources, and activities to discover students' misconceptions and lead them to find the correct answers by studying evidence.

\section{Interview Results}

The interviews were important tools for eliciting less tangible aspects of the teachers' methods, including their motivations, philosophical positions, and personal priorities. The most important result of the interviews was perhaps the discovery that all six teachers in the case study had either been identified as gifted learners at some point during their academic careers or had family members who were. More generally, their motivations to teach and ideas about teaching can be interpreted in terms of their own training. These results tend to suggest that self-selection is a good method for identifying and training teachers skilled in constructivist techniques. The reasons each teacher chose to work with gifted students were broadly similar. Nancy chose to work with students on "independent projects and they enjoyed science." She also attended workshops and classes to provide enrichment experiences for them and was excited to teach them science for fun. Sammy was asked if she would like to participate in the lowa Excellence program and she said yes, "because it is a way to get students interested in science. My advanced courses at the high school are small. I need more students who are interested in and brave enough to take them." Abby said, "science has long been neglected" and said she thought it was critical to maintain interest in science among middle school students. She further said that the typical "read the book and answer the questions" approach does not motivate students. Amy credited her love of teaching science, and she seemed to connect best with gifted students, probably because she had been identified as one. She reported having "done 
volunteer work with the gifted and they are my favorite group to work with." These statements tend to reinforce the idea that both self-selection and special training are important aspects of good constructivist teachers.

On the subject of training, the teachers identified a need for more preparation to teach gifted students. Five of the six science teachers reported that they had to undergo professional development and take courses from other institutions to prepare themselves to teach the gifted science students. Beth noted, "that there wasn't much ever [in her training] about whom gifted students are or how they learn."

Overall, the teachers expressed a desire for more focus on effective methods for instructing gifted learners. "I would love a set of strategies for teaching abstract concepts more concretely," Emily said.

"Three of the six science teachers found it important for teachers to understand that gifted (especially highly gifted) students are fundamentally different from others in the ways that they think and approach problem solving. Where highly structured activities are very appropriate for some students, gifted students often need and want less structured (or differently structured) activities. They further reiterated that some teachers just want to accelerate gifted students into higher grades without regard for those differences, an approach that completely ignores the depth that gifted students can bring to their work. Amy stated, "Teachers also need to understand that bringing a gifted student's passion into their work can make all the difference when motivating gifted students".

\section{Discussion}

These findings provided mixed evidence regarding the value of the professional development program as currently taught, at least to the research participants in this study. The program was observed to have a positive affect in encouraging the teachers to review their own teaching methods and to make relevant changes to improve their use of constructivist techniques. However, the program did not significantly improve knowledge of constructivist techniques nor did it increase the use of the techniques in teaching practice.

Two of the participants reported that they did not encounter constructivist teachers during their $\mathrm{K}-12$ years or in their classes in college. However, they did report encountering this type of teaching in the science education dept at the university they attended for their post graduate degrees. Initially, the teachers reported that they saw a reaction to inquirybased teaching in their students that remind them of their first introduction to constructivism.

The students were perceived to be uncomfortable with the constructivist methodology, because the instructors did not always tell them what to do. They had more freedom in what they were learning. Amy said succinctly, "Students seem to get nervous if they are not told what to do and how to think." Constructivism offers the potential to not only teach students subject matter, but to also teach them to be independent critical thinkers.

There was a mix of experiences reported by the science teachers in the surveys. Although they reported and increased understanding of the added value of constructivism, particularly in helping keep gifted students motivated and interested in science, they also expressed concern over the high level of preparedness required by the teacher and the challenge that preparation presents. Ambivalence was demonstrated when the idea of using constructivism in the normal class sessions, not just the extracurricular sessions, which include students of all academic levels and abilities was introduced.

Teachers also commented on the weakness of constructivism in that constructivism assumes that students will automatically integrate their hands-on experiences into their view of the world. Criticisms of constructivism include the assumption that students can think abstractly enough to be able to generalize experiments in a science lab to real-world settings. Students are presumed to learn best by doing things with their hands, and that is not necessarily the case. Abby offered that it is "extremely difficult for lower level learners to process what they do in constructivist lessons". Emily had reservations about constructivism because it "... doesn't take into account standardized testing requirements, curriculum requirements, or instructions from districts that emphasize memorization over understanding".

\section{Conclusions}

This research project provides a wealth of useful information regarding the skills and knowledge needed to teach gifted children at the middle school level. It also describes how professional development programs such as ISP can be used to enhance these skills, while providing opportunities for gifted middle school children to reach their full potential. The study has demonstrated that teachers often use constructivist-teaching methods with the belief that they are the most appropriate in teaching science. Within the context of an extra-curricular program, these can be especially effective in teaching gifted students of middle school age. The investigator is aware, however, that expansion of science education for gifted students, particularly as extracurricular programs, will raise issues regarding cost, fund-raising, existing teacher workloads and remuneration, as well as the need for developing fair, unbiased student selection criteria. Although the long-term benefits of such programs are likely to be significant, the significant expense and workloads involved in establishing and running them should not be underestimated.

The results of this study suggest that further research is necessary in various areas. First, a major concern was the perceived conflict between constructivist teaching styles and standardized curriculums and testing. A deeper exploration of the multidimensional relationship between gifted students, their teachers, and the expectations of and opportunities in their school systems is necessary to truly examine that conflict. Additionally, this study suggests that teachers who are specifically trained in gifted student instruction feel more confident teaching gifted students-close examination of such training programs for teachers is warranted. Finally, this study suggests that gifted students in middle school tend not to be accelerated at the rate they should, and that the reasons for not accelerating them tend to rely on relatively simplistic 
judgments regarding students' social needs; it seems that addressing those social needs and accelerating students academically need not be mutually exclusive, and further research should examine ways of doing both.

\section{REFERENCES}

1. Adams, C.M., \& Pierce, R.L (2007) Science, Elementary. In National Association of Gifted Children's,

2. Critical issues and practices in gifted education. (pp. 589-590)

3. American Association for the Advancement of Science. (1993). Benchmarks for science literacy, Project

4. 2061. New York: Oxford University Press.

5. Bloom, B.S. (1985). Generalizations about talent development. In B.S. Bloom (Ed) Developing talent in

6. young people(Pp.507-549) New York: Ballantine Books

7. Burry-Stock, J.A. and Oxford, R.L. (1994). Expert science teaching educational evaluation model

8. (ESTEEM) for measuring excellence in science teaching for professional development. Journal of Personnel Evaluation in Education, 8, 267-297.Sannella, M. J. 1994 Constraint Satisfaction and Debugging for Interactive User Interfaces. Doctoral Thesis. UMI Order Number: UMI Order No. GAX95-09398., University of Washington.

9. Cohen, D., McLaughlin, M., \& Talbert, J. (1993). Teaching for Understanding. San Francisco, CABrown, L. D., Hua, H., and Gao, C. 2003. A widget framework for augmented interaction in SCAPE.

10. Ford, D. (1994). Nurturing resilience in gifted black youth. Roeper Review, 17(2), 80-85

11. Kerr, B. (1985). Smart girls, gifted women. Columbus, OH: Ohio Psychology Publishing Company

12. Lockwood, A. (1992a). The De Facto Curriculum? Focus in Change, 6, 8-11

13. Lockwood, A. (1992b). Whose Knowledge Do We Teach? Focus in Change, 6, 3-7.

14. National Center for Educational Statistics, National Assessment of Educational Progress (NAEP), 1999

15. Long-Term Trend Assessment, p.15.

16. National Research Council (NRC), 1996. National Science Education Standards. Washington, DC: National

17. Academy Press..

18. No Child Left Behind Act,20 USC6301 (2001) http://www.law.cornell.edu/uscode/20/6301.html

19. Olson, S., \& Loucks-Horsley, S. (2000). Inquiry and the national science education standards: A guide for

20. teaching learning. Washington,DC: National Academy of Sciences

21. Rutherford, J., \& Ahlgren, A. (1989) Science for All Americans. Washington, DC: American Association for the Advancement of Science, 42:1, 254-266.

22. Yager, R.E. (1991). The constructivist learning model. The Science Teacher, 51, 52-57.

Dr. Abha Singh is an Assistant Professor of Science Education at Western Illinois University in the Department of Curriculum and Instruction where she teaches undergraduate and graduate courses. Dr. Singh's current research is in the area of integration of science and literacy. She frequently presents at international, national and state conferences. She earned her Ph.D. in science education from the University of lowa,USA 